\title{
Saskatchewan Doukhobor Russian: A Disappearing Language
}

\author{
Veronika Makarova \\ Department of Religion and Culture, University of Saskatchewan, Saskatoon, Canada \\ Email:v.makarova@usask.ca
}

Received June $7^{\text {th }}, 2012$; revised August $1^{\text {st }}, 2012$; accepted August $8^{\text {th }}, 2012$

\begin{abstract}
This paper introduces the history and surveys some features of Saskatchewan Doukhobor Russian, a nearextinct variety of the Russian language spoken in the Canadian prairie province of Saskatchewan. The paper also outlines the reasons for the language loss in Saskatchewan.
\end{abstract}

Keywords: Doukhobor Russian; Minority Language Maintenance; Heritage Language; Endangered Language; Doukhobor Studies; Slavic Studies

\section{A Brief History of Saskatchewan Doukhobors}

The beginning of the 21 st century is marked in linguistics by an increased interest in the topic of minority language maintenance (e.g., Crystal, 2000; Bradley \& Bradley, 2002; Janse \& Sijman, 2003), since language is seen as "the key to and the heart of culture" (Hinton \& Hale, 2001: p. 9). Canada plays a ma- jor leadership role in promoting cultural and linguistic diversity (e.g., Migus, 1975; Canada, 1993, 1996; Aboriginal Peoples; Hudon, 2007). Most linguistic studies in Canada concentrate on the maintenance of the official languages (e.g., Hewson, 2000; Canada, 2007; Johnson, 2006), aboriginal (Freeden, 1991; Canada, 2005) and Métis languages (Douaud, 1982). However, less attention has been devoted to heritage languages. Some available publications demonstrate that heritage languages are fundamental to the multicultural nature of Canada, since they are a part of the "human capital," and contribute to the group and individual identities of speakers and their appreciation of different cultures (Anthony, 1983; Cummins \& Danesi, 1990; Pendakur, 1990; Chiswick, 1992; Danesi, McLeod, \& Morris, 1993; Edwards, 1998; Jedwab, 2000; Chiswick \& Miller, 2003). Studies of minority languages contribute to the development of linguistics and sociolinguistics along with a number of other disciplines, such as anthropology, sociology, politics, cultural studies, geography, history and language history (Aitchison, 1991; Anderson, 1991; Bolinger, 1980). Audio and video re- cords of minority and endangered languages help to preserve their samples for posterity.

Unique varieties of Russian are spoken in Canada by Doukhobors and their descendants. Doukhobors or "Doukhobortsy" were religious dissenters who split from the Orthodox Church in the 17th and 18th centuries (Tarasoff, 2002). The Doukhobors lived in communes, they rejected private property, orthodox church and all forms of violence (including wars and military drafts) which led to their forced resettlements to the outskirts of the Russian Empire in the beginning of the $19^{\text {th }}$ century (mostly to Georgia and Azerbaijan). In the late 1800s until the early 1900s, about 7500 Doukhobors immigrated to Canada with the hope of pursuing their ideal of "toil and peaceful life" (Man- ning, 2005; Rhoads, 1960). They were assisted financially in this move by Leo Tolstoy and American Quakers
(Tarasoff, 2002; Manning, 2005; Rhoads, 1960).

In Canada, the Doukhobors first settled in what is nowadays parts of Saskatchewan (in those days Districts of Assiniboia and Saskatchewan) around North Saskatchewan river, Blaine Lake and Duck Lake as well as in eastern parts of Saskatchewan (then district of Assiniboia) close to the current border with the neighbouring province of Manitoba (in and around the modern towns of Veregin, Canora, Kamsack, Pelly, Arran and Yorkton). Initially, the Doukhobors were given some lands, they were allowed to have communal ownership of the land and their own schools, and were exempt from military drafts. In 1905-1907, their privileges were cancelled and 258,000 acres of their lands (almost all their cultivated land) were confiscated by the government and reverted back to the crown. Following these events, many Doukhobors left Saskatchewan and moved to Alberta and British Columbia. However, a small number of the Doukhobors remained in Saskatchewan and shifted to the private (family household) ownership of the lands and cultivating the land by individual families (i.e., households) (Tarasoff, 2002; Schaarschmidt, 2011).

Currently, Saskatchewan has no areas of compact settlement where Doukhobors could lead their traditional lifestyle. However, in a few towns, one still finds small functioning Doukhobor communities with members getting together for prayers, traditional festivals and other activities. The history and culture of the Doukhobors have attracted the interest of historians and anthropologists (Waiser, 2005; Rak, 2001, 2004; Inikova, 1999; Tracie, 1996; Klymasz \& Tarasoff, 1995; Stupnikoff, 1992; Sulerzhitsky, 1982) as well as of public media (Manning, 2005; Wilson, 2010; Saskatoon, 2011). Recently the Doukhobor community drew the attention of mass media in connection with the Vancouver Winter Olympic Games, since the Olympic torch relay route passed through Blaine Lake and representatives of the Doukhobor community presented the torch runner Brian Edy with the traditional Russian bread-and-salt (https://docs.google.com/View?id=dnxrfb8_442c6vjbcf5).

The current number of Doukhobors and their descendents in the province has been estimated between 8000 and 11,000 people (Tarasoff, 2002), whereas only about 450 individuals in Saskatchewan identified their religion as Doukhobor during the 
2001 Census. Saskatoon (the largest city of Saskatchewan by the number of people) has the Doukhobor community of about 150 people, of whom about thirty individuals are actively involved with the religious rituals, festivals and community events. The majority of the Doukhobors and their descendents have lost the command of spoken Russian. While in Canada overall the index of Russian language maintenance in the Doukhobor families is estimated at $60 \%$ (Schaarschmidt, 2011), only very few of Saskatchewan Doukhobors maintain a high level of command of Russian. The number of speakers of Doukhobor Russian in Saskatchewan rapidly decreases annually, as the age of the generation still maintaining fluent Russian speaking ability is between 75 and 95 years. The total number of fluent speakers of Doukhobor Russian in Saskatchewan is about 30 - 40 people. In other words, the unique language variety of Saskatchewan Doukhobor Russian is on the very brink of extinction and will disappear completely within the next 5 - 10 years.

A small number of Doukhobors and their descendants have retained the language over a few generations (Golubeva-Monatkina, 2004). Saskatchewan Doukhobor Russian variety has never been described before. No speech samples of Saskatchewan Doukhobor Russian are available beyond the pilot project of the researcher (a part of which was conducted jointly with the Department of Phonetics, St. Petersburg University). As noted, the variety is on the very brink of extinction, since the last speakers who maintained proficiency in the language are in the age group over 70 years old. Making speech records of Saskatchewan Russian is of crucial importance for preserving this important part of the cultural heritage of the province. Although some attempts to put together bibliographies of Doukhobor-related sources have been undertaken by Rak (Annotated Doukhobor Bibliography) and Tarasoff (http://www.spirit-wrestlers.com/), no bibliography of materials related to Doukhobor Russian (including Saskatchewan Doukhobor Russian) is available.

\section{The Sources of Information about Canadian Doukhobor Russian}

An impressive amount of work at compiling bibliographies and exploring historic reference materials connected with the life of Canadian Doukhobors has been undertaken by researchers and scholars many of whom are descendents of Canadian Doukhobors (Rak, 2004; Tarasoff, http://www.spirit-wrestlers.com; Kalmakoff, http://www.doukhobor.org). Very little information is available, however, about the language of Canadian Doukhobors. A few features of Doukhobor Russian spoken in British Columbia have been described in papers by Gunter Schaarschmidt (Schaarschmidt, 1995, 2005, 2008, 2012). No information is available on the language of Saskatchewan Doukhobors. The speech of Saskatchewan Doukhobors has never been recorded or subjected to linguistic inquiry (except for the pilot projects by the researcher). However, as will be shown in the next section, it has a number of unique characteristics and it requires immediate recording and archiving before its complete disappearance within the next decade or so.

Our study is conducted on the basis of observations of the Doukhobor community and its ritual gatherings in Saskatoon, Saskatchewan, informal conversations/interviews with ten Doukhobor community members in $2010-2011$, as well as examinations of Saskatchewan Doukhobor choir hymns.

\section{Characteristic Features of Saskatchewan Doukhobor Russian Speech}

\section{Dialectal influences from Southern Russia and Ukraine}

This section surveys some features of Canadian Doukhobor Russian speech and compares them with the observations of Doukhobor speech undertaken in Saskatoon Doukhobor community.

Already during the formative period in the development of Doukhobor Russian as a distinctive variety of the language, after the first compact settlements of the Doukhobors in the area of the Molochna river (close to the city of Marioupol, modern Ukraine) in Taurida and Ekaterinoslav Gubernias (modern Ukraine), the variety acquired some features of southern Russian and Ukrainian dialects. After the forced relocation of the Doukhobors into the Caucuses Mountains area in the second quarter of the 19th century, the Doukhobor Russian language has been reported to borrow some words from the local languages (Georgian, Azerbaijani, etc.) (Schaarschmidt, 2011). However, in the speech of modern Saskatchewan Doukhobors, we did not encounter any loan words from these languages.

After the Doukhobors moved to Saskatchewan, Canada, the language came into another round of contact with Ukrainian (and to a lesser extent Polish) dialects spoken by immigrants from Ukraine and Poland. According to the words of one of the Doukhobor informants, "we had some farmhands from Ukraine working in our homestead, and we understood them really well, and after a while we stopped noticing which language is which and started mixing Ukrainian and Russian words". As noted by Schaarschmidt (2011), it is often very difficult to differentiate between southern Russian and Ukrainian influences in Canadian Doukobor Russian. We did observe in the Russian speech of Saskatchewan Doukhobors some examples of such influences at the lexical level.

The following dialectal word forms represented in Russian and Ukrainian dialects were observed in the speech of Saskatchewan Doukhobors: “слухать" (hear, imperfective/ref standard "слушать”), “послухать" (hear, perfective/ ref standard “послушать”), “гутарить” (speak), “трошки” (a little). Three informants referred to one's own and other women's husbands as "мой/ее человек" (instead of the standard "мой/еe муж”), which is analogous to Ukrainian “мой чоловік”). The same informant also used the word "пряха" (which in standard Russian stands for "yarn-spinner") in the meaning "прялка" (distaff). This word form "пряха" with the meaning "distaff" is also found in Russian Kursk and Perm dialects (Даль, 18801882). One more lexeme displaying Ukrainian and possibly Polish influences is the word "налешник" used by some informants with respect to the traditional Doukhobor dish of stuffed crepes. Russian southern dialects had an analogous lexeme "налистник" which has recently made its way into standard Russian; in Ukrainian, this dish is called "налисник", and in Polish, the form is "naleśnik", i.e., the Doukhobor word form is the closest to the Polish one. This can be explained either by the initial Polish influence during the time when some ancestors of modern Doukhobors lived in Galicia (an area of the Russian Empire later split between Poland and Ukraine), or by more recent contacts of the Doukhobors with Polish immigrants in Saskatchewan. 


\section{Archaic Forms in the Ritual Style}

At least two major styles are distinguished in Saskatchewan Russian: ritual and conversational (Schaarschmidt, 2012). The term "ritual" used by Schaarschmidt is not very fortunate, as Doukhobors reject church and rituals. However, by tradition and for lack of a better term, it is used in current paper as well. Ritual style is used during ritual gatherings for the reading of prayers and singing of hymns. According to previous research, the ritual language is full of archaic Church Slavonic lexemes (Schaarschmidt, 2011). However, while examining the songs and prayers in use by the Doukhobor communities of Saskatchewan, we found only a relatively small number of archaic forms. It may be possible that due to the large extent of Doukhobor Russian language loss in Saskatchewan, only relatively simple texts are selected from prayers and hymns.

Among the examples of archaic lexis, we observed the forms, such as "испасение" (salvation/ref standard "спасение"), “сполнившись” (overflown/ref standard “наполнившись”).

\section{Semantic Changes}

We have registered the semantic broadening of the word "тулуп" (a loose shaped fur-coat) which in the speech of Saskatchewan Doukobors can also mean "upper garment" or "coat".

\section{Morpho-Syntactic Forms}

The analysis of ritual texts displays a range of specific morpho-syntactic features of Doukhobor Russian. The analysis confirms that the destruction of the Neuter gender category in the nominal system, which was observed in the speech of the Doukhobors in British Columbia (Schaarschmidt, 2011), is also present in Saskatchewan Doukhobor Russian. Nouns, adjectives and pronouns which have neuter gender in standard Russian acquire forms similar to feminine gender. Examples of this process from Saskatchewan Doukobor hymns include “да святится имя твоя" (hallowed be Thy name/ref standard “имя твое"), “наша знамя" (our banner, ref standard "наше знамя"), "нашу солнцу" (our sun, Accusative case/ref standard "наше солнце"). We also found some new and exciting evidence that points to the fact that some word forms of neuter nouns in cases other than Nominative and Accusative do not "convert" into feminine declension, but keep the forms typical of the neuter declension class, e.g., the form "солнца луч" (a ray of sun). Thus, although in the Nominative and Accusative cases the nouns with neuter gender acquire the forms overlapping with feminine gender, in other cases they may preserve the declension forms of the neuter nouns, i.e., the paradigm of the neuter gender has shifted towards a merge with feminine gender, but this merge has not been completed. It seems like there may be a separate declension class of Doukhobor nouns which we call here "X-neuter" (i.e., formerly neuter nouns shifting into a different class and having overlapping forms). We illustrate this with a comparison of Doukhobor and standard Russian partial paradigms in example 1 below. Unfortunately, we so far found only a few instances of the use of X-neuter nouns in cases other than Nominative and Accusative, so this hypothesis needs more evidence.

$\begin{array}{ccccc} & \text { D X-N } & \text { Stand N } & \text { Stand F } & \text { Stand M (inanm) } \\ \text { N } & \text { солнца } & \text { солнце } & \text { рама } & \text { стол } \\ \text { G } & \text { солнца } & \text { солнца } & \text { рамы } & \text { стола } \\ \text { A } & \text { солнцу } & \text { солнце } & \text { раму } & \text { стол }\end{array}$

Conversational Russian Doukhobor variety has morphosyntactic forms found in substandard/dialectal Russian, e.g., "они хочут, вы хочете" (they want, 3rd pers pl, you want, 2nd pers $\mathrm{pl).}$

\section{Phonological Features and Pronunciation}

In both ritual and conversational Doukhobor Russian style, the use of allophone [y] (voiced dorsal-velar approximant) has been reported earlier (Schaarschmidt, 2011). While this sound is typically associated with Ukrainian and Southern Russian dialects, it has also been found as a free alternant with [g] in standard Moscow Russian in the word "бога" (Аванесов, 1956). In the speech of Doukhobors from British Columbia, [y] and $[\mathrm{g}]$ were reported to freely alternate in all the words containing the letter " $\Gamma$ " intervocalically and in the word beginnings followed by a vowel (Schaarschmidt, 2011). In the speech of Saskatchewan Doukhobors, we did find some examples of al-

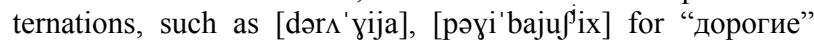
(precious, pl), “погибающих" (perishing)" along with [dər^'goj], [pəgi'bajufix] (precious, sg). However, [y] has the predominant usage in these positions, e.g., "Бога" (God, Gen case), "восторгам" (excitements, Instr case) ['boya], [vss'toryam]. This sound is considered by Saskatchewan Doukhobors to be a "trademark" which differentiates them from the speakers of standard Russian. We also observed that in the word end position, the letter « $\Gamma$ » is pronounced not as $[\mathrm{k}]$ as in standard Russian, but as $/ \mathrm{x} /$, e.g., [plux] for "плуг” (a plough).

Our analysis of the pronunciation of ritual Doukhobor texts also revealed a number of differences in the pronunciation of the letter "e".

1) word-final letter "e" in inflexional suffixes tends to be pronounced like [ja]:

a) Adjectival (and pronomial) inflexional suffixes containing the final letter "e" are pronounced not as [je], as in standard Russian, but as [ja], е.g., “дорогие” (precious), “никакие" (none) [dərs'yija, niks'kija]

b) Imperative plural and 2nd person plural, indicative present forms of verbs ending with the inflexional suffix "-те" are pronounced not as $\left[\mathrm{t}^{\mathrm{j}} \mathrm{I}\right.$ ], as in standard Russian, but as [t’a], e.g., “давайте” (lets), “слышите” (hear, 2nd Pers pl), are pronounced as $\left[\mathrm{d}_{\Lambda}{ }^{\prime} v a j \mathrm{t}^{\mathrm{j}} \mathrm{a}\right.$, 'slif $\mathrm{it}^{\mathrm{j}} \mathrm{a}$ ] Similar forms are found in some Ukrainian and Belorussian dialects.

2) In other word classes, word-final "e" is pronounced not as a reduced raised and fronted [e] or [I], but as [i], e.g., "вместе"

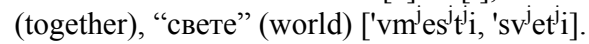

3) The pronouns “своей”, “ему”, “всей”, “моей” are pronounced not as standard [sv $\Lambda^{\prime} j e j, \mathrm{jI}^{\prime} \mathrm{mu}, \mathrm{f}^{\mathrm{j}} \mathrm{s}^{\mathrm{j}} \mathrm{ej}$ ], but as [sv 'joj, j $\left.\Lambda^{\prime} \mathrm{mu}, \mathrm{fs}^{\mathrm{j}} \mathrm{oj}, \mathrm{m} \Lambda^{\prime} \mathrm{joj}\right]$.

4) The letter "e" after a vowel is pronounced not as [je], but as [i] "обещает" (promise, 3rd pers sg) [əbı'’jart]. This feature is found in northern Russian dialects.

5) In some cases, word-final "e" letter is pronounced as [a], e.g., "тоже" ['toza].

The words with the "devisive" soft sign are pronounced without [j], е.g., страданья, упованья [str $\left.\Lambda^{\prime} \operatorname{dan}^{\mathrm{j}} \mathrm{a}, \mathrm{up} \Lambda^{\prime} \operatorname{van}^{\mathrm{j}} \mathrm{a}\right]$ as opposed to standard [ $\operatorname{str}^{\prime} \Lambda^{\prime} d a n^{j} j a$, up $\left.\Lambda^{\prime} v^{j} n^{j} j a\right]$. This feature is found in Ukrainian and Belorussian dialects.

Inflexional suffix of adjectives “ый, ий” are pronounced as [aj], e.g., “яркий” (bright), “старинный” (ancient) ['jarkaj, st $\Lambda$ 'rinnaj]

Word-final palatalization is weaker than in standard, e.g., 
“любовь” $\left[\mathrm{l}^{\mathrm{j}} \mathrm{u}^{\prime}\right.$ bof $\left.\mathrm{f}^{j}\right]$ (love) is pronounced like [ $\left.\mathrm{l}^{\mathrm{j}} \mathrm{u}^{\prime} \mathrm{bof}\right]$.

\section{The Language Loss and Its Reasons}

As mentioned, the Russian language of Saskatchewan Doukhobors is on the brink of extinction. According to Gunter Schaarshmidt (2006), "at the beginning of the 21 st century, the Doukhobor Russians in Canada find themselves at a crucial stage in the maintenance of their language, i.e., they are facing a shift from a rate of $60 \%$ to one of $30 \%$ of maintenance, possibly within the span of one generation, at best two generations. There is already significant language shift in the Saskatchewan group of Doukhobors, not to mention even the isolated population segments in Alberta. Thus far, language use has been most vigorous in the West Kootenay region of British Columbia". However, our observations of the Saskatchewan Doukhobor community have shown that language is almost extinct with the shift range approaching $0 \%$ maintenance, as the only group of fluent speakers of Doukhobor Russian in the province are in the age group between 70 and 95 . Even within this group of fluent speakers, Russian is no longer the dominant language. The speakers use English in the majority of everyday language functions; they are more comfortable speaking English than Russian, and all of them exhibit features of strong Russian language attrition. The Doukhobors in Saskatchewan have a limited use of Russian for prayers and hymns during the ritual gatherings, as well as use some Russian cliché phrases during and outside of ritual gatherings. Some Doukhobors also use Russian in the rare situations when they need to communicate with members of the local Russian community or visitors from Russia who do not speak fluent English.

At the Diaspora level, the language loss manifests itself in the daily communication in English, even during and after the ritual gatherings and in the shift towards the recital and singing of psalms and hymns either from English transliterations or in English translations. The first Doukobor community to shift towards prayers in the English translation was the community of Blaine Lake, since the members of this community hoped that this measure would help to attract the youth. English transliterations and translations did not have any effect on attracting the younger generation (there are virtually no people younger than in their 60s attending the Doukhobor ritual gatherings), but they facilitated the loss of the Russian language in general and of literacy in Russian in particular.

The Doukhobors themselves do not see the dangers of translating the original texts, since they do not understand what a gigantic layer of cultural connotations and semantic nuances is lost in translation. They are however concerned for the quality of translation: "As long as we get the meaning, it's OK. What concerns us more is the poor quality of translations."

Transliterated variants of prayers and hymns do not follow any standardized transliteration system, and they inadequately render "inconvenient" for transliteration Russian letters (like «ы»). This makes the reading of prayers and hymns more challenging than solving a crossword puzzle. On the other hand, the transliterations render rather well the specific features of Dukhobor Russian pronunciation (as described above), which would be lost in the standard Russian orthography. An example of such a transliteration followed by its Russian reconstruction is given below. This particular hymn is also used by Evangelists and in other Christian denominations, but the ending is somewhat different in the Doukhobor variant.

Dahraheeyah meenohteh nahm Boh dahrahvahl

Mhe ooveedeelee brahtev, seestohr

Ah Eesoos dahrahhoy s nahmee beht ahbeeshahl

Mhe dahdehm Yahmoo v sehrtseh prahstohr.

Дорогие минуты нам Бог даровал.

Мы увидели братьев, сестер.

А Иисус дорогой с нами быть обещал,

Мы дадим Ему в сердце простор.

At the level of individual language speakers, we observed functional narrowing accompanied by the strong interference from English and code-switching between Russian and English, particularly in cases when the informant forgets or does not know some word or expression. For example, one informant used the English word "accident", because she did not know the Russian word for it.

Most reasons for the loss of the Doukhobor Russian language in Saskatchewan are in common with the typical factors which have been named in research as decreasing ethnolinguistic vitality of minority languages. These are mixed marriages (a few Doukhobors mentioned that since their spouse did not speak Russian, they did not speak Russian with their children either), the lack of contact with the home country, the lack of the areas of compact settlement, overall small number of community members, rural areas of living, etc. (Holmes, 2001). Some other locally-specific reasons that have lead to the disappearance of the Doukhobor Russian in Saskatchewan are described below.

\section{The Destruction of the Traditional Lifestyle of the Doukhobor Communities Due to Urbanization and Emigration from Saskatchewan}

As was mentioned earlier in Section I, in early 20th century, a larger part of the Doukhobor community were forced into moving away from Saskatchewan after they had been prohibited from having communal land property and their lands had been confiscated. The Doukhobors who remained in Saskatchewan had to change to individual homesteads, where one family worked together on their land. Only Russian was initially spoken in the families. The work on homesteads in the conditions of severe Saskatchewan winters where the thermometer often falls below minus 30, and sometimes even below minus 40 degrees Celsius was extremely hard. With the industrialization of Canada in 1870s-1920s, farming was gradually becoming less profitable and less prestigious, and the children of farmers started moving into cities, where they lost their Russian speaking networks, and close family contacts were getting torn. While in the end of the 19th/early 20th centuries, $70 \%$ of Canadians lived in rural areas (Oreopoulos, 2005), by 2006 this figure dropped down to $19.8 \%$ (Statistics Canada). Until its recent economic boom, Saskatchewan remained one of the most underdeveloped economically and industrially provinces of Canada, and the internal (within Canada) emigration from Saskatchewan was very high. The peak of emigration occurred in 1989-1990, when in that year alone, 35 thousand people left the province (Elliott, 2010; Waiser, 2005). The Doukhobors were striving to give education to their children, so that their lives would be less difficult. However, after receiving university and professional diplomas, the young generation were leaving Saskatchewan in searches for better employment opportunities; they were no longer interested in the old traditions, rituals and the language of the older generation. "The life 
has changed", as the Saskatchewan Dokhobor informant said. Almost all the members of the Doukhobor community of Saskatoon (the largest city in Saskatchewan) have children and grandchildren who live in other provinces of Canada or in the USA, which prevents frequent communication and passing the cultural traditions over generations. In our informal interviews, the Doukhobors expressed regrets that they have nobody to speak Russian with on the daily basis and that they have little opportunity not only of talking with their grandchildren in Russian, but also of seeing them. The Doukhobors understand that it leads to the language loss, but they are powerless to change this situation.

\section{Canadian School System}

Initially Canadian Doukhobors taught their children at home or in their own schools where Russian was the language of instruction. This situation started to change with the introduction of the obligatory school in Saskatchewan in 1909. First, the school attendance was required only for children from 7 to 13 years old and it was sufficient to spend only 100 days at school per year, which made it possible for the children to keep helping their parents with agricultural work. In 1917, the School Attendance Act was passed, in which children aged 7 to 14 were required to attend school during the whole school year. In 1922, the school age was raised to 15 years (Oreopoulos, 2005). The obligatory school education meant education in English, which was made the sole language of instruction (with the exception of Francophone children attending their first year of elementary school). Even up to the present day, Russian has never been taught in any public Saskatchewan school even as a foreign language. Accordingly, as soon as the children from Doukhobor families were forced to attend public schools, a typical three-generation language shift occurred from Russian to English. As the oldest Saskatchewan Doukhobors recall, beginning with the 1930s-1940s, after coming back from school, the children continued speaking with each other in English. Even when their parents spoke to them in Russian, the children responded in English.

\section{Discrimination of Doukhobors in Canada, Prejudice and Anti-Soviet Propaganda}

While talking about the Doukhobors, Canadian mass media always refer to their persecutions in Russia (e.g., Saskatoon Sun, 2011), but fail to mention that the discrimination (although of a different nature) continued in Canada as well. Besides the confiscation of the earlier given lands in Saskatchewan in early 20th century, the Doukhobors were pressured into swearing an oath of allegiance to the British monarch - an act which goes contrary to the traditional Doukhobor religion as it acknowledges the authority of God, but not of earthly monarchs and governmental institutions. These measures coincided in time (likely not accidentally) with the First Russian revolution of 19051907. The Doukhobors who tried to escape from Saskatchewan to British Columbia to protect their communal lifestyle and spiritual values, underwent further discrimination. In British Columbia, they again were forced to abandon some of their lands. A small group of radical Doukhobors known as "The Sons of Freedom" tried to fight back for their rights. Their protest methods included burning their own dwellings and belongings as well as nude marches. This lead to the perception of all Doukhobors as communists (due to their communal lifestyle and disrespect of private properties) and nudists (Betke, 1974: p. 4). The state fought with the "Sons of Freedom" using all possible force that included taking children away from their "politically incorrect" parents and placing them in orphanages, reform schools for delinquent children, other Doukobor families and training schools (www.gov.bc.ca). The provincial government of British Columbia issued a "statement of regret," somewhat short of an apology, with no financial compensation for the victims of these measures (www.gov.bc.ca). The Federal government never acknowledged violations of the human rights of the Doukhobors in Canada.

Anti-Soviet and anti-Russian propaganda in Canada during the Cold War (late 1940s - early 1990s) also strongly contributed to the negative image of the Doukhobors. As one informant put it, "Wherever something bad happened, it was the Russians' fault." As the result, many Doukhobors felt ashamed of their ethnicity and their cultural heritage and were trying to hide them. One informant pointed out that when he went to school in the late 1940s, he changed his name and lied about the place he was from, because the name of his native Doukhobor village would have given him away and made him an object of ridicule and bullying at school, as was the case with many other Doukhobor children.

Currently, the attitudes to Doukhobors in Saskatchewan are changing for the better. The Doukhobor community has friendly exchanges and sometimes combined services with other Christian denominations. The members of the Doukhobor community participate in many public cultural events, such as Christmas Interconfessional Choirs' performances, Saskatoon Exhibition, exhibitions of the works by famous Doukhobor artists, like William Perehudoff, etc. Some Doukhobor descendents study their history, gather and publish historic documents (e.g., Tarasoff, Kalmakoff). Unfortunately, for the preservation of Saskatchewan Doukhobor Russian, these changes came a couple of decades too late.

\section{The Consequences of Language Loss}

We have observed the following consequences of language loss in the Doukhobor community:

- Generation gap;

- Discontinuation of the cultural tradition;

- Washing away of the religious traditions and practice.

As explained above, the loss of language leads to translations and transliterations of prayers and hymns, which decreases their idiosyncrasies, depletes semantic layers and cultural connotetions. The loss of language also leads to the destruction of family tradition and family connection. For example, one Doukhobor descendent asked the researcher to translate her ancestral family documents into English (passports and travelling documents dating back to early 20th century). The Doukhobor descendent could not read them herself and was not even sure about the names of her grandparents, as their names were anglicized.

One more Doukhobor descendent asked the researcher to translate the inscriptions on the graves of her parents, as they were in Russian, and she could not read them. Another Doukhobor descendent asked the researcher to transliterate some Doukhobor prayers so that she could read them to her father who was on his deathbed in a local hospital. 
One Doukhobor community member rendered her regrets for the loss of language and the cultural tradition in the following words: "It is a pity everything is lost. Everything we stood for will collapse".

\section{Measures to Document the Language and Culture of Saskatchewan Doukhobors}

The buildings of the Doukhobor community settlement in Veregin closed in 1917 and were turned into a National Historic Site in 2006 and are protected by the federal Government. Unlike architectural constructions, the preservation of the language of Saskatchewan Doukhobors never attracted any interest from the Canadian or provincial governments. Despite the near-extinct status of the language, all the research applications aimed at archiving and documentation of the speech of Saskatchewan Doukhobors that were submitted by researchers from the University of Saskatchewan over the last six years were rejected. In the response to a grant application submitted to Saskatchewan Heritage Foundation in 2010, the committee chair responded that "It appears the Board's priority for the next while may well be the bricks and mortar of built heritage conservation initiatives, with other categories being a lower priority" (from an e-mail addressed to the author). Canadian governmental bureaucrats do not understand that bricks and mortar may last for a few more years, but languages disappear without any trace, whereas the cultural value of a language is incomparably greater than that of any physical structure, since "it is through languages that culture is maintained" (LeviStrauss, 1963).

Currently, a small joint research project between the linguists of Saskatchewan and St. Petersburg (Russia) universities is in progress. The project is aimed at creating and archiving sound records of Saskatchewan Doukhobor Russian. The project is financed by the Russian governmental organization "the Russian World" (Русский Мир), and although it cannot prevent the loss of Saskatchewan Doukhobor Russian, at least its samples will be preserved for future generations.

\section{REFERENCES}

Aboriginal Peoples (2012). Guide to the records of the government of Canada. URL (last checked 27 July 2012).

http://www.collectionscanada.ca/02/0201200109_e.html

Aitchison, J. (1991). Language change: Progress or decay (2nd ed.). Cambridge: Cambridge University Press.

Anderson, A. B. (1990). German settlements in Saskatchewan: Origin and development of German Catholic, Lutheran, Baptist, Mennonite and Hutterite communities. Saskatoon: Saskatchewan German Council.

Anderson, B. (1991). Imagined communities: Reflections on the origin and spread of nationalism (2nd ed.). London and New York: Verso.

Anthony, L. (1983). Heritage languages: A Bibliography. Regina: Multicultural Council of Saskatchewan.

Avanesov, R. I. (1956). Fonetika sovremennogo russkogo literaturnogo jazyka. Moscow: Moscow University Press.

Betke, C. (1899-1909). The Mounted police and the Doukhobors in Saskatchewan. Saskatchewan History, 27, 1-14.

Bolinger, D. (1980). Language: The loaded weapon. London: Longman.

Bradley, D., \& Bradley, M. (2002). Language endangerment and language maintenance. London: Routledge.

Canada. Statistics on Official languages of Saskatchewan. Office of the Commissioner of Official Languages. URL (last checked 27 July 2012).

http://www.ocolclo.gc.ca/youth_jeunes/tools_outils/stat_can_sk.asp? Lang=English
Canada (1993). Education and Canada's First Nations: A strategy for change. Ottawa: Royal Commission on Aboriginal Peoples.

Canada (1996). Report of the royal commission on aboriginal peoples. Ottawa: The Commission on Aboriginal People.

Canada (2005). Task force on aboriginal languages and cultures towards a new beginning: A foundational report for a strategy to revitalize First Nation, Inuit and Métis languages and cultures: Report to the Minister of Canadian Heritage. Ottawa: Task Force on Aboriginal Languages and Cultures.

Canada (2007). Communities speak out, hear our voice: The vitality of official language minority communities: Report of the Standing Committee on Official Languages. Ottawa: Standing Committee on Official languages.

The Canadian Encyclopedia. URL (last checked 12 January 2011). $\mathrm{http} / / /$ www.thecanadianencyclopedia.com/index.cfm?PgNm=TCE\& Params $=$ A1ARTA0008280

Chiswick, B. R. (1992). Immigration, language and ethnicity: Canada and the United States. Washington DC: Aei Press.

Chiswick, B. R., \& Miller, P. W. (2003). The complementarity of language and other human capital: Immigrant earnings in Canada. Economics of Education Review, 22, 469-480. doi:10.1016/S0272-7757(03)00037-2

Crystal, D. (2000). Language death. Cambridge: Cambridge University Press. doi:10.1017/CBO9781139106856

Cummins, J., \& Danesi, M. (1990). Heritage languages: The development and denial of Canada's linguistic resources. Toronto: Our Schools/ Ourselves Education Foundation.

Dalj, V. I. (1880-1882). The thesaurus of the live Great-Russian language. URL (last checked on 27 July 2012). http://vidahl.agava.ru/

Danesi, M., McLeod, K. A., \& Morris, S. (1993). Heritage languages and education: The Canadian experience. Oakville, ON: Mosaic Press.

Douaud, P. C. (1982). All mixed: Canadian Métis sociolinguistic patterns. Working Papers in Sociolinguistics, 101, 34.

Edwards, J. (1998). Language in Canada. Cambridge: Cambridge University Press.

Elliott, D. (2010). Demographic trends in Saskatchewan and their impact on labour market supply. The New Democartic Party Policy Review, 27 March 2010.

Freeden, S. M. (1991). On the critical list: Sociolinguistic survey of indigenous languages in Saskatchewan. Saskatoon: University of Saskatchewan.

Golubeva-Monatkina, N. I. (2004). Russkaia emigrantskaia rech' v Kanade kontsa XX veka: Teksty i kommentarii. Moscow: Editorial URSS.

Hewson, J. (2000). The French Language in Canada. Munich: LINCOM Europa.

Hinton, L., \& Hale, K. (2001). The Green book of language revitalization in practice. Cambridge: Cambridge University Press.

Holmes, J. (2001). An introduction to sociolinguistics (2nd ed.). London: Longman.

Hudon, M. (2007). Language regimes in the provinces and territories. Ottawa: Parliamentary Information and Research Service.

Inikova, S. A. (1999). Doukhobor incantations through the centuries. Ottawa: Legas.

Janse, M., \& Sijmen, T. (2003). Language death and language maintenance: Theoretical, practical and descriptive approaches. Amsterdam: John Benjamins.

Jedwab, J. (2000). Ethnic identification and heritage languages in Canada. Montréal: Éditions Images.

Johnson, M. (2006). A sharper view: Evaluating the vitality of official language minority communities. Ottawa: Office of the Commissioner of Official Languages.

Klymasz, R. B., \& Tarasoff, K. J. (1995). Spirit wrestlers: Centennial papers in honour of Canada's Doukhobor heritage. Ottawa: Canadian Museum of Civilization.

Levi-Strauss, C. (1963). Language and the analysis of social laws. In B. Blount (Ed.), Language, culture and society: A book of readings (2nd ed., pp. 143-152). Prospect Heights, IL: Waveland.

Manning, P. E. (2005). Dedicating the past: Doukhobor caves part of historic settlement. Saskatoon Sun, Sunday, 28 August.

Migus, P. M. (1975). Sounds Canadian: Languages and cultures in multi-ethnic society. Toronto: Martin. 


\section{MAKAROVA}

Newman, M. (1990). Men artists. Biographical dictionary of Saskatchewan artists. Saskatoon: Fifth House Publishers.

Oreopoulos, P. (2005). Canadian compulsory school law and their impact on educational attainment and future earnings. Ottawa: Statistics Canada.

Pendakur, R. (1990). Speaking in tongues: Heritage language maintenance and transfer in Canada. Eric: ED339214.

Rhoads, J. E. (1960). A day with the Doukohobors: An interesting account of a visit to the Russian settlement in Saskatchewan. Philadelphia: William H. Pile's Sons.

Robertson, S. (1994). Diverse exhibit fits purpose of the Kenderdine Gallery. The Saskatoon Star Phoenix, June 1994.

Rak, J. (2001). Doukhobor autobiography as witness narrative. Biography, 24, 226-241. doi:10.1353/bio.2001.0020

Rak, J. (2004). One hybrid discourse of Doukhobor identity: The freedomite diary from Agassiz prison. In D. Beneventi, L. Canton, \& L. Moyes (Eds.), Adjacencies: Minority writing in Canada. Toronto: Guernica.

Rak, J. Annotated Doukhobor bibliography. URL (last checked 27 July 2012). http://www.ualberta.ca/ jrak/doukhobor_bibliography.htm

Stupnikoff, S. G. (1992). Historical saga of the Doukhobor faith, 17501990s. Saskatoon: Apex Graphics.

Saskatoon Sun (2011). Where did the Doukhobors originate? Saskatoon Sun, 20 February 2011, 4.

Schaarschmidt, G. (1995). Aspects of the History of Doukhobor Russian. Canadian Ethnic Studies, 27, 197-204.

Schaarschmidt, G. (2005). Four norms-one culture: Doukhobor Russian in Canada. In R. Muhr (Ed.), Standardvariationen und Sprachideologien in verschiedenen Sprachkulturen der Welt. Standard Variations and Language Ideologies in different Language Cultures around the World (pp. 137-150). Wien: Peter Lang Verlag.

Schaarschmidt, G. (2008). The ritual language of the British Columbia Doukhobors as an endangered functional style: Issues of interference and translatability. Canadian Slavonic Papers, 50, 102-122.

Schaarschmidt, G. (2012). Doukhobor internal and external migrations: Effects on language development and structure. In: V. Makarova (Ed.), Russian language studies in North America (pp. 235-260). London: Anthem Press.

Statistics Canada. URL (last checked 27 July 2012).

http://www.statcan.gc.ca/start-debut-eng.html

Sulerzhitsky, L. A. (1982). To America with the Doukhobors. Regina: Canadian Plains Research Center.

Tarasoff, K. J. (2002). Spirit wrestlers: Doukhobor pioneers' strategies for living. Brooklyn, NY: Spirit Wrestlers Publishing.

Tracie, C. J. (1996). Toil and peaceful life: Dukhobor village settlement in Saskatchewan, 1899-1918. Regina: Canadian Plains Research Center.

Waiser, B. (2005). Saskatchewan: A New history. Calgary, Alberta: The Fifths House.

Wilkin, K. (1977). William Perehudoff. Art International, 21, 16.

Wilson, P. (2010). Doukhobor tradition carries on one loaf at a time. The Star Phoenix. URL (last checked 27 July 2012). http://www2.canada.com/saskatoonstarphoenix/news/third_page/stor $\mathrm{y} \cdot \mathrm{html}$ ?id=7423d822-72ac-47e6-8770-6f35cd33ad1d\&p=2 